\title{
Transnationalizing Comparative Law
}

Some twenty years ago, one of the top law schools in the United States decided to end all its courses in comparative and foreign law. This was done in the expectation that the then-fashionable end of history would also mean the end of diversity of legal systems and the global triumph of US law. Students of the future would merely need to learn 'law' (which meant US law) and be able to practice anywhere in the world. Needless to say, the prediction turned out to be premature. The school is now, like every other US law school, advertising its special competence in comparative law for its curriculum and for lawyers today.

We should remember that reports on the death of comparative law, as suggested by the editors of this journal, are always, to paraphrase Mark Twain, greatly exaggerated. ${ }^{1}$ Comparative law does not die so easily. Nor, however, does it remain unchanged. Rather, and unsurprisingly, comparative law is constantly evolving, in imperfect parallel with the development of law, and society, at large. Lawrence Rosen once suggested "we may have to renounce comparative law as we have at times known it in order to save it."2 But the truth is that comparative law will always exist whether we (who is that anyway?) renounce it or not. If comparative lawyers of old refuse to go along with changes, it merely means that others will do it for them-grandiose economist for whom laws are mere data points for statistical analysis; ambitious young US scholars of constitutional law with often scant exposure to foreign societies and modes of thought but a keen interest in promoting their causes; brilliant lovers of French poststructuralist thought and its propensity for theory and meta-theory without the need to engage with actual foreign law. It is easy to ridicule these new developments from the standpoint of traditional comparative law. But what would be more helpful is to understand them as signs of

1 Mathias Siems, The end of comparative law, (2007) 2 Journal of Comparative Law 133-150; see already Mathias Reimann, The end of comparative law as an autonomous subject, 11 Tul. Eur. \& Civ. L.F. 49 (1996). Cf. Peer Zumbansen, Transnational Comparisons : Theory and Practice of Comparative Law as a Critique of Transnational Governance', in Maurice Adams and Jacco Bomhoff (eds), Practice and Theory in Comparative Law (2012) 186, 187 ("comparative law is not dead-or is it?"). Siems himself does not appear to believe in the field's death; he has recently published an important treatise on the subject and is now, indeed, speculating about the far future of comparative law. See Mathias Siems, Comparative Law (Cambridge University Press 2014); id., Comparative Law in the 22nd Century [in this issue?] ${ }^{2}$ Lawrence Rosen, Beyond Compare, in Pierre Legrand \& Roderick Munday (eds), Comparative Legal Studies: Traditions and Transitions (Cambridge University Press 2003) 493, 510. 
a change in the discipline. And in order to understand change we need to understand how comparative law was before we can have a sense of how it will be.

\section{1) Comparative Law in the Age of the Nation State}

What are reasons for this change? The most obvious reason is our ongoing paradigm shift from what we called a Westphalian model of the world to a globalized understanding of the world. ${ }^{3}$ In the Westphalian model, all law was either national (state) law or international law. The model created three important factors for comparative law, 4 which we can date, very imprecisely, around 1600, 1800, and 1900, and which we can name, not much more precisely, as: state, positivism, science.

\section{a) The State}

The first of these factors is the rise of the sovereign state-the idea that the state is all-encompassing (Hobbes) and sovereign (Bodin). This implies the idea that the state has the exclusive power to make law. As a consequence, the focus in comparative law has come to be exclusively on states and their laws. Non-state laws like religious laws or customary law have all but disappeared from such studies (except when they were, as is the case with Islamic law in predominantly Muslim countries, turned into state law); responsibility for them has been deferred to other disciplines like religious studies or anthropology. Standard treatises on comparative law may contain non-state laws such as religious laws or customary laws in the discussion of legal families, but in microcomparison, these laws are all but forgotten. ${ }^{5}$ The new lex mercatoria, regardless of whether it is an autonomous law or (more plausibly) an amalgam of state and non-state law, is almost never looked at for comparative purposes. Merely non-state codifications like the UNIDROIT Principles of Comparative Law are considered. By and large, non-state law plays practically no role in comparative law; the field remains largely blind to the growth of global legal pluralism.

\section{b) Positive Law}

The second of these factors, namely the focus of comparative law on positive law, did not happen at the exact same time, at least outside of public law. ${ }^{6}$ Private law in

\footnotetext{
${ }^{3}$ See Ralf Michaels, Law and Globalization: Law Beyond the State, in Globalisation and Law: Law Beyond the State, in Law and Social Theory 287-303 (Reza Banakar \& Max Travers eds, Hart, 2nd ed, 2013).

${ }^{4}$ Cf. Patrick Glenn, Quel droit compare?, Revue de Droit.Université de Sherbrooke 43 (2013) 23; see already, e.g., William Twining, Globalization and Comparative Law, Maastricht Journal 6 (1999) 217.

${ }^{5}$ A notable exception is Werner Menski, Comparative Law in a Global Context-The Legal Systems of Asia and Africa (2nd ed. 2006).

${ }^{6}$ See further Ralf Michaels, Of Islands and the Ocean: The Two Rationalities of European Private Law, in Roger Brownsword, Leone Niglia \& Hans-Wolfgang Micklitz (eds.), Foundations of European Private Law (Hart 2011) 139.
} 
$17^{\text {th }}$ and $18^{\text {th }}$ century Europe was still largely thought of as transnational; comparisons were made, if at all, between Roman and Germanic law, but not between the laws of different states. This idea that law is positive law resulted from the expansion of the state's law-making power to private law, a fruit of the enlightenment that ripened fully with the French code civil of 1804. Legal positivism does not mean merely legislation, in the tradition of législation comparée (although comparative law has always given, and continues to give, disproportionate prominence to those.). But it does mean a near exclusive focus on law as official pronouncements in the name of the state. In an important way, the much-trumpeted difference between "law in the books" and "law in action" that we find so important in comparative law amounts to little more than the difference between scholarship and legislation on the one hand and court decisions on the other. Law in society rarely plays a role in traditional comparative law. It is sometimes said that the trend to positive law meant the end of comparative law, because it made lawyers narrow their focus from transnational to national law. This is only half-true. At the same time, the idea that law, including private law, was something national, created the possibility of difference between different laws, and as such made comparison possible.

\section{c) Legal Science}

The third factor, the idea that comparative law can be done scientifically, emerged in comparative law around the end of the $19^{\text {th }}$ century, and in this limited sense the frequent claim that comparative law was born at the Paris Congress of 1900 has some justification. ${ }^{7}$. Of course, the rise of science and scientific method has a longer prehistory, in Western thought generally and also in comparative law. But it was arguably around 1900 that such an approach became generally accepted in the discipline. This scientific approach thus used was, for many, an approach of autonomous legal science, in this sense characterized by the German idea of Rechtswissenschaft. Although some comparative lawyers at the time, especially in France, flirted with the use of sociology, to a large extent the method of comparative law was not so different from the method of law more generally. This is not to say that comparative law had no critical aim, quite the contrary. Comparatists directed their critique against national parochialism and backwardness. In this sense, comparative law was a very modernist project.

\section{2) Comparative Law in the Age of Transnationalism}

These three aspects - a focus on state law, a focus on positive law, an emphasis on a legal-scientific approach to comparative law-continue to dominate much comparative law today. It is obvious that all three of them clash with the emergence of globalization as the new paradigm to replace the Westphalian model.

${ }^{7}$ Ralf Michaels, Im Westen nichts Neues? 100 Jahre Pariser Kongreß für Rechtsvergleichung - Gedanken anläßlich einer Jubiläumskonferenz in New Orleans, RabelsZ 66 (2002) 97. 


\section{a) Beyond the State}

The state has lost its exclusive role in the global sphere. It has not become unimportant-some states have arguably increased their power and their importance-but it has lost its independence. States have become, to use the concept that Keohane and Nye popularized, interdependent; their role depends on and in turn influences that of other states, and much of their activity now happens in cooperation with other states. This is clearest in entities like the European Union or the WTO that create separate supranational bodies, but it is true more generally. In this context it matters also that states have become disaggregated, as Annemarie Slaughter has demonstrated-rather than viewing the state as a uniform actor we should look at the actions of its different agencies, which are sometimes in conflict with each other. Moreover, we must learn to look not just at states as lawmakers but also to focus on the significant lawmaking by non-state actors-arbitrators, institutions (so-called rule-formulating agencies), multinational corporations, ethnic communities, etc. In this context, religious law also reemerges as an important object of comparative law.

All of this makes comparative law, if taken seriously, considerably more complex. Not only do we need to account for a broader variety of laws and legal systems than before. Moreover, and more importantly, we can no longer assume legal systems to be entities that are independent from each other. A comparison of English and French law, to use just a simple example, would be woefully incomplete if it only compared them as national systems. Such an analysis needs to account for the fact that both of them, as member states of the European Union, are not only part of the same legal system, but also exert influence on each other through their mutual role within EU law. An analysis of corporate law in Vietnam would be incomplete if it analyzed the legal transplants of US corporate law as a mere transfer between independent states and not also as an occurrence of imposition reminiscent of neocolonialism, a direct exertion of regulatory power from the United States (and other countries) on Vietnam, though the use of experts, education, conditional loans, etc. An analysis of the use of comparative law in the US Supreme Court cannot merely look at the court as a representative of the United States at large. It must instead recognize that such use of foreign sources takes place in a complex setting of both international relations with foreign countries and non-state actors and intrastate relations with other branches of government and with the individual States.

\section{b) Beyond Positive Law}

Second, the waning of legal positivism also has implications on comparative law. Our studies of law as positive law have clearly become insufficient. We have learned about the importance of soft law. We are learning, again, that we must take seriously religious laws. We have learned to take more seriously the fact that the role that positive law plays in different societies is different. On the one hand, positive law may have hardly any effect on society in some countries where it enforced arbitrarily or not at all and where it is considered, by large parts of the society, as illegitimate. In this regard comparative law is required to take functional equivalents of positive law into account-cultural norms and societal practices, rituals, traditions, and so forth. On the other hand, we have learned how activists 
and interest groups use even law that is not binding-treaties that have not been ratified, invocations of human rights that have a global appeal although they are not binding law-for strategic advances. ${ }^{8}$ If we ignore such developments our comparative law studies become less relevant.

\section{c) Beyond Legal Science}

Third, and finally, it is not clear whether a scientific approach to comparative law in the sense of Rechtswissenschaft can still be maintained (if it ever could). The most obvious reason is that legal science itself provides no criteria for the evaluation of law other than those derived from the law itself. It is for this reason that many comparative studies, while often strong in their country reports, are so vague and unsatisfying in their actual comparison: they can demonstrate similarities and differences between legal systems, but their legal arguments can neither explain nor evaluate these differences, because they are country-specific.

The consequence in contemporary comparative law is, for many, the endorsement of extralegal sciences, in the hope to achieve neutrality. This explains the rise of comparative law and economics, especially in the form of statistical comparative law (somewhat grandiosely called empirical comparative law, as though statistical data were the only empirical data we have.) ${ }^{9}$ It also explains the rise of political science as a disciplinary focus on the materials of comparative law.

This embrace of the social sciences is, in on way, very promising. It helps comparative lawyers to develop an outside perspective of the law, a way of measuring it. But this comes, more often than not, with a price. ${ }^{10}$ Far too often, social scientific studies in comparative law fall into one of three traps, all related. The first of those traps is the mere replacement of legal with economic language, with no gain made. Not much is gained, for example, if we merely replace the comparative law concept of 'liability for others' with that of a principal-agent relation. The second trap is the collapse into abstract models derived from economic reasoning as the yardstick against which legal systems are to be measured, because such a priori systems have little value for the real world. The third trap, finally, is that social scientific studies often fail to take law seriously in its complexity and specificity. ${ }^{11}$

Arguably, this turn to the social sciences falls short. By turning to economics and political science we often merely try to recapture the objectivity that we lost with the decline of our faith in legal doctrine. We replace legal positivism with social science positivism and get nowhere closer to a true understanding of legal cultures.

\footnotetext{
8 Sally Engle Merry,Human Rights \& Gender Violence-Translating International Law into Local Justice (2006).

9 For an overview, see Holger Spamann, Empirical Comparative Law, Annual Review of Law and Social Science 11 (2015)

10 See Ralf Michaels, Comparative Law by Numbers? Legal Origins Thesis, Doing Business Reports, and the Silence of Traditional Comparative Law, 57 Am. J. Comp. L. 765 (2009).

11 See Ralf Michaels, The Second Wave of Comparative Law and Economics?, U. of Toronto L. J. 59 (2009) 197.
} 
In order to truly understand the foreign and our relation to it we will have to turn to other disciplines-cultural anthropology, cultural studies, science and technology studies. These disciplines have traditionally been hesitant about comparison because they fear the abstraction inherent in comparison, and they have been hesitant about the transnational because of their interest in local knowledge. That fear is not unjustified, and we can learn from it. But we can also, from our experience, contribute to overcoming it, or at least managing it. Comparison may always be reductive, but it can be fruitful as long as we remain aware of such reduction, and as long as we feel we can still generate genuine understanding.

\section{3) The Place of Comparative Law Today}

The question for the future of comparative law is misleading. It is exactly the problem of comparative law is that it, like socialism and paradise, has too often been promoted as being in the future and not the present, as something yet to come for a world yet to come. Rather than prepare comparative law for a future that may or may not come, we should adapt it for a present for which it is in many regards inadequate. The critique of national parochialism that inspired the 1900 Paris Congress remains relevant today. But comparative lawyers must also be critical of those tendencies in globalization that attempt to overcome the state without putting something else at its place, of new universalizing and totalitarian projects of governance that deny local cultures and specific experiences, that attempt to replace local democracy with the delocalized logic of the marketplace. It is our knowledge of specificities and generalities (the micro and the macro), of differences and similarities, of diversity and interconnection, that we should bring to the table of modern governance projects. And we should voice our critique when the ignorance of such knowledge leads to terrible consequences.

It is tempting to suggest that comparative law has become either useless or universal. Either we no longer need it (because globalization is anathema) or it has become universal (we are all comparatists now). We can easily recognize that both claims are false, and that it would therefore be dangerous to replace comparative law with something else, be it transnational law, global law, legal pluralism, new governance, or the like. Between parochial nationalism and totalizing uniformism, comparative law maintains its important role of distinction and connection, of creating both proximity and distance, of allowing the other to be other and yet reach out to it. Comparative law is dead? Long live comparative law! 